\title{
Growth characteristics of fish species Gerres filamentosus (Cuvier, 1829) in coastal zone, Quang Binh province
}

\author{
Đặc điểm sinh truởng của cá Móm gai dài Gerres filamentosus (Cuvier, 1829) ở \\ vùng ven biển tỉnh Quảng Bình \\ Short communication
}

Vo, Van Thiep*; Tran, Thi Yen; Nguyen, Thi Huong Binh; Huynh, Ngoc Tam

Department of Agriculture, Forestry and Fisheries, Quang Binh University, 312 Ly Thuong Kiet, Dong Hoi, Quang Binh, Vietnam

\begin{abstract}
The research was conducted from October 2013 to March 2014 by using the method applied in the current ichthyology study by GV Nikolski, Pravdin IF, OF Xakun, NA Buskaia and Mai Dinh Yen. Fish samples were collected in the coastal area of Quang Binh province. The study results showed that Gerres filamentosus (Cuvier, 1829) had the length romf $52 \mathrm{~mm}$ to $230 \mathrm{~mm}$, corresponding to the weight from $4 \mathrm{~g}$ to $185 \mathrm{~g}$. The age structure of the fish was simple that consisted of four age groups $\left(0^{+}-3^{+}\right)$, the annual growth rate was relatively fast, the growth equation following Von Bertalanffy was as: $\left.\mathrm{L}_{\mathrm{t}}=234.4 \times\left[1-\mathrm{e}^{-0.35(\mathrm{t}+0.996}\right)\right], \mathrm{W}_{\mathrm{t}}=373.4 \times\left[1-\mathrm{e}^{-0.0244(\mathrm{t}+0.2388)}\right]^{3.0676}$.
\end{abstract}

Nghiên cưu được thực hiện tù̀ tháng 10 năm 2013 đến tháng 3 năm 2014 bằng nhũng phuơng pháp đang được áp dụng trong các nghiên cưu ngu loại hiện nay của G.V. Nikolski, I. F. Pravdin, O. F. Xakun, N. A. Buskaia và Mai Đình Yên, mẫu cá được thu tại vùng ven biển của tỉnh Quảng Bình. Kết quả nghiên cứu đã cho thấy cá Móm gai dài có chiều dài dao động tù $52 \mathrm{~mm}-230 \mathrm{~mm}$, tuơng úng với khối luợng tù $4 \mathrm{~g}-185 \mathrm{~g}$. Cấu trúc tuổi cá Móm gai dài đơn giản, gồm 4 nhóm tuổi $(0+-$ $3+)$, tốc độ tăng trường hàng năm tương đối nhanh, phương trình sinh trường theo Von Bertalanffy có dạng $L t=234,4 x[1-e-0,35(t+0,996)], W t=373,4 x[1-e-0,0244(t+0,2388)] 3,0676$.

Keywords: fish, Gerres filamentosus, the growth characteristics, sustainable exploitation

\section{Introduction}

Gerres filamentosus (Cuvier, 1829) which belongs to Gerridae family, Perciformes order, live mostly in shallow water, muddy bottom, coastal sand and estuaries from India to the island of Admirality [5]. This fish species has high economic value, because it is a source of comprehensive food and protein which are really necessary for human intellectual and physical development. Due to those benefits, people's exploitation caused influence on the distribution and population of Gerres filamentosus. Studies on the biological characteristics of this fish species in order to propose solution to protect the sustainability of fishery resources in general and Gerres filamentosus species in particular are essential. Breeding and artificial breeding of fish seed to supply farmers are important directions for sustainable management and development of
Gerres filamentosus. Therefore, the study on growth characteristics in order to provide food components for Gerres filamentosus is necessary and urgent.

\section{Subjects and methodology}

\subsection{Subject}

Species: Gerres filamentosus (Cuvier, 1829)

Family: Gerridae

Order: Perciformes

Samples were processed while they were still fresh and measured the index of the body length $\left(\mathrm{L}\right.$ and $\left.\mathrm{L}_{0}\right)$ and weights ( $\mathrm{W}$ and $\mathrm{W}_{0}$ ). Relied on fish scales, the age of fish was determined [7]. There were about 30-50 scales on each sample taken. 
Determining the correlation between length and weight:

Correlations between length and weight of Gerres filamentosus fish was indicated by the growth equation of RJH Berverton - SJ Holt (1956): $\mathrm{W}=\mathrm{ax} \mathrm{L}{ }^{\mathrm{b}}$ [7].

Where:

$\mathrm{W}$ : body weight of fish (g); L: body length of fish (mm); a, b: correlation coefficient.

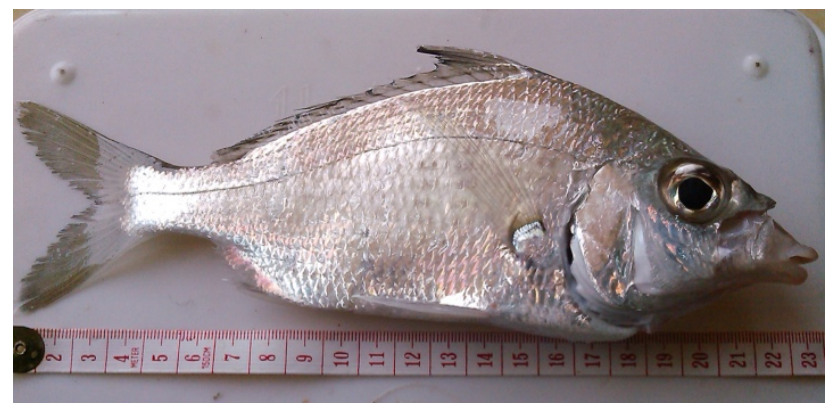

Figure 1. Gerres filamentosus

\section{Determining age:}

Use scales were used to determine the age of Gerres filamentosus. The observed scale pattern was soaked in $\mathrm{NaOH}$ solution $4 \%$ to remove grease, dirt and pigment stuck on them. Then they were rinsed with water, wiped dry. The year round observation was done by using binocular magnifier and scales radius measurement was done by using a microscope fitted with an eyepiece micrometer.

\section{Growth rate:}

The method of Rosa Lee (1920) was used to determine the increase in length of Gerres filamentosus, with the equation: $L_{t}=\frac{V_{t}}{V}(L-a)+a[6,7]$. Where:

$\mathrm{L}_{\mathrm{t}}$ : the fish length at the age of " $\mathrm{t}$ " to be found (mm); L: the current fish length; $\mathrm{V}_{\mathrm{t}}$ : lateral distance from the center to the line of year round at the age of $\mathrm{t}(\mathrm{mm}) ; \mathrm{V}$ : scales radius measured from the center to the edge of the scales; a: fish size onset psoriasis ( $\mathrm{mm})$. The coefficient "a" was determined by the length and size of fish scales.

Equation can be expressed in the form: $\mathrm{L}_{\mathrm{t}}=(\mathrm{L}-\mathrm{a}) . \mathrm{V}_{\mathrm{t}} / \mathrm{V}$ $+\mathrm{a}(*)$

Table 1. Correlation between length and weight of Gerres filamentosus in the coastal zone, Quang Binh province

\begin{tabular}{cccccccc}
\hline \multirow{2}{*}{ Age } & \multirow{2}{*}{ Gender } & \multicolumn{3}{c}{ Length $(\mathrm{mm})$} & \multicolumn{3}{c}{ Weight W $(\mathrm{g})$} \\
\cline { 3 - 8 } & & $\mathrm{L}_{(\min -\max )}$ & $\mathrm{L}_{\text {average }}$ & $\mathrm{SE}$ & $\mathrm{W}_{(\min -\max )}$ & $\mathrm{W}_{\text {average }}$ & $\mathrm{SE}$ \\
\hline \multirow{2}{*}{$0^{+}$} & Juv & $52-82$ & 72.0 & 3.3 & $4-8$ & 5.7 & 0.8 \\
& Male & $60-105$ & 78.3 & 7.1 & $5-11$ & 7.1 & 1.1 \\
& Female & $70-115$ & 90.7 & 9.9 & $6-13$ & 8.5 & 1.2 \\
$1^{*}{ }^{+}$ & Male & $105-148$ & 128.8 & 9.1 & $11-49$ & 28.6 & 8.9 \\
& Female & $110-152$ & 132.3 & 8.3 & $12-51$ & 31.8 & 9.7 \\
$2^{+}$ & Male & $135-175$ & 155.9 & 8.5 & $36-75$ & 55.7 & 9.8 \\
\multirow{2}{*}{$3^{+}$} & Female & $140-186$ & 161.4 & 7.6 & $40-85$ & 64.4 & 10.6 \\
& Male & $152-200$ & 178.8 & 10.8 & $50-130$ & 78.6 & 15.9 \\
& Female & $143-230$ & 186.5 & 19.8 & $41-185$ & 85.9 & 25.7 \\
\hline
\end{tabular}

The study results showed that the fishes in $1^{+}$and $2^{+}$age groups had the length from $105-186 \mathrm{~mm}$ and the corresponding weight from 11-85g, accounting for the
Put $\mathrm{Y}=\mathrm{L}_{\mathrm{t}} ; \mathrm{X}=\mathrm{V}_{\mathrm{t}} ; \mathrm{b}=(\mathrm{L}-\mathrm{a}) / \mathrm{V} ; \mathrm{a}=\mathrm{a}$;

Equation (*) will be put in the form: $\mathrm{Y}=\mathrm{a}+\mathrm{bX}$

We take the general form and find the coefficients $a$ and $b$.

$\left\{\right.$ n. a + b. $\sum X=\sum Y$

a. $\sum X+$ b. $\sum X^{2}=\sum X Y$

After $L_{t}$ is achieved, the growth rate of the fish is calculated in the formula:

$\mathrm{T}_{\mathrm{t}}=\mathrm{L}_{\mathrm{t}}-\mathrm{L}_{(\mathrm{t}-1)}[6,7]$

Where:

$\mathrm{T}_{\mathrm{t}}$ : the length growth of fish at the age of $\mathrm{t}(\mathrm{mm}) ; \mathrm{L}_{\mathrm{t}}$ : the fish length at the age of $\mathrm{t}(\mathrm{mm})$; $\mathrm{L}_{(\mathrm{t}-1)}$ : the fish length at the age of $(\mathrm{t}-1)(\mathrm{mm})$.

\section{Defining the parameters of the Bertalanffy growth equation:}

- Bertalanffy growth equation for length $(\mathrm{mm})[6,7]$.

$\mathrm{L}_{\mathrm{t}}=\mathrm{L}_{\infty}\left[1-\mathrm{e}^{-\mathrm{k}(\mathrm{t}-\mathrm{to})}\right]$

Where:

$\mathrm{L}_{\mathrm{t}}$ : fish length at the age of $\mathrm{t} ; \mathrm{L}_{\infty}$ : maximum length of fish $(\mathrm{mm})$; $\mathrm{k}$ : partition coefficient of protein weight in the body fish; $t$ and $t_{0}$ : current age and the original fish (years).

- Bertalanffy growth equation of weight $(\mathrm{g})[6,7]$.

$\mathrm{W}_{\mathrm{t}}=\mathrm{W}_{\infty}\left[1-\mathrm{e}^{-\mathrm{k}(\mathrm{t}-\mathrm{to})}\right]^{\mathrm{b}}$

Where:

$\mathrm{W}_{\mathrm{t}}$ : fish weight at the age of $\mathrm{t}(\mathrm{g}) ; \mathrm{W}_{\infty}$ : maximum weight of fish (g); b: coefficient correlation between length and weight of fish.

\section{Research results}

\subsection{Correlation between length and weight}

During the growth and development process of fish, there was a relationship between the increases in length and body weight. After analyzing 339 individuals, the results showed that length of Gerres filamentosus ranged from 52 $230 \mathrm{~mm}$ and the weight from 4-185 g. They were distributed in four age groups. Correlation between the length and weight of collected Gerres filamentosus is shown in Table 1. 
highest percentage $(65.65 \%)$. Followed by the $3^{+}$age group accounting for $19.76 \%$ had the length from $143-230 \mathrm{~mm}$ and the weight from $41-185 \mathrm{~g}$. For the $0^{+}$age group accounting for $14.59 \%$, the length ranged from $52-115 \mathrm{~mm}$, corresponding to the weight from $4-13 \mathrm{~g}$.

Table 1 showed that in the same age group, the size and weight of female fishes are bigger than those of male ones. The correlation between fish size and weight of Gerres filamentosus was determined by the equation $\mathrm{RJH}$ Beverton - SJHolt (1956): $\mathrm{W}=5204 \times 10^{-8} \times \mathrm{L}^{2.9367}$. Thus, the relationship between size and weight growth of Gerres filamentosus is represented by a correlation coefficient of $\mathrm{R}^{2}=0.9673$. This is correlated, which means that the size increases, the weight also increases.

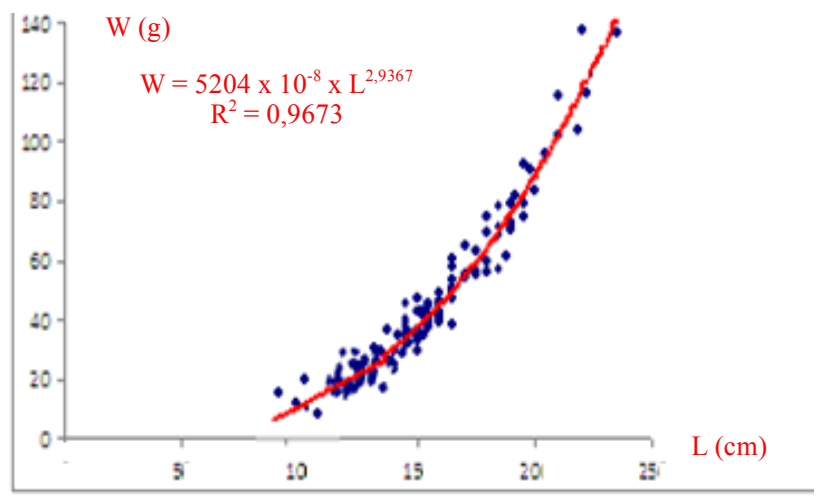

Figure 2. Correlation between the length and weight of Gerres filamentosus.

As can be seen in Figure 2, the growth levels in length and weight of the investigated fish individuals in each age group were not different. The rapid increase in length was expressed in individuals with lower age group $\left(0^{+}, 1^{+}, 2^{+}\right)$.
By the later stages $\left(3^{+}\right)$fish length growth slowed down, but the growth in weight became faster. The rapid increase in weight of individuals in the older age group was due to the accumulation of nutrients to ensure the possibility of sexual reproduction and migration.

\subsection{Age structure of population}

Among four age groups of Gerres filamentosus, the $2^{+}$age group accounted for the highest percentage (34.65\%) of the total number of individuals collected. Followed by the $1^{+}$ age group accounted for $25.69 \%$. The $3^{+}$age group made up $19.76 \%$, and the $0^{+}$age group accounted for the lowest percentage (14.59\%). Most fishes were caught at the age group of less than $2^{+}(80.24 \%)$, with the weight ranging from $4-85 \mathrm{~g}$. This group of fishes has relatively small size, yet high commercial value and they have not given birth or have given birth for the first time. This is an additional source to ensure the natural reproductive process of Gerres filamentosus. In fact, exploitation of fishes at this age will reduce seed sources, which can lead to drastically decrease their populations in the near future. Therefore, applying the efficient measures for sustainable exploitation, protection and management of these resources is necessary.

\subsection{Annual length growth rate}

Based on the results of the length and size scales corresponding to the empirical equations Rose Lee (1920), we determined that value of coefficient "a" was 11.33. Reversing the growth equation of Rose Lee (1920), we have: $\mathrm{L}_{\mathrm{t}}=(\mathrm{L}-11.33) . \mathrm{V}_{\mathrm{t}} / \mathrm{V}+11.33$. From this equation, the annual length and growth rate of the investigated fish are shown in Table 2.

Table 2: Annually length and growth rate of Gerres filamentosus

\begin{tabular}{|c|c|c|c|c|c|c|c|c|c|}
\hline \multirow{2}{*}{ Age } & \multirow{2}{*}{ Gender } & \multirow{2}{*}{$\mathrm{L}_{1}(\mathrm{~mm})$} & \multirow{2}{*}{$\mathrm{L}_{2}(\mathrm{~mm})$} & \multirow{2}{*}{$\mathrm{L}_{3}(\mathrm{~mm})$} & \multirow{2}{*}{$\mathrm{T}_{1}(\mathrm{~mm})$} & \multicolumn{2}{|l|}{$\mathrm{T}_{2}$} & \multicolumn{2}{|l|}{$\mathrm{T}_{3}$} \\
\hline & & & & & & Increase $(\mathrm{mm})$ & $\%$ & Increase $(\mathrm{mm})$ & $\%$ \\
\hline \multirow{2}{*}{$1^{+}$} & Male & 77.8 & & & 77.8 & & & & \\
\hline & Female & 79.8 & & & 79.8 & & & & \\
\hline \multirow{2}{*}{$2^{+}$} & Male & 93.2 & 131.8 & & 93.2 & 38.6 & 41.1 & & \\
\hline & Female & 96.3 & 136.3 & & 96.3 & 40.0 & 41.6 & & \\
\hline \multirow{2}{*}{$3^{+}$} & Male & 106.2 & 1509.0 & 169.9 & 106.2 & 44.7 & 42.0 & 19.0 & 17.8 \\
\hline & Female & 107.5 & 152.8 & 172.0 & 107.5 & 45.3 & 42.1 & 19.3 & 17.9 \\
\hline \multicolumn{2}{|c|}{ Average } & 93.5 & 143.0 & 171.0 & 93.5 & 42.2 & 41.7 & 19.2 & 17.9 \\
\hline
\end{tabular}

Table 3. Parameters of growth length and weight

\begin{tabular}{ccc}
\hline Growth parameters & Following length & Following weight \\
\hline $\mathrm{L}_{\infty}(\mathrm{mm}), \mathrm{W}_{\infty}(\mathrm{g})$ & 234.4 & 373.4 \\
$\mathrm{t}_{0}$ & -0.9960 & -0.2388 \\
$\mathrm{~K}$ & 0.3500 & 0.0244 \\
\hline
\end{tabular}

The results in Table 2 showed that in the wild environment, at the time of 1 year-old the average length of Gerres filamentosus males reached $77.8 \mathrm{~mm}$, and that of females was $79.8 \mathrm{~mm}$. At the time of 2 year-old males reached $131.8 \mathrm{~mm}$ and females reached $136.8 \mathrm{~mm}$ in length. At the
3 years old of age length of males was $169.9 \mathrm{~mm}$, and that of females was $172 \mathrm{~mm}$. The everage length of fish at the first year was $93.5 \mathrm{~mm}$; in the 2 nd year the value increased up to $42.2 \mathrm{~mm}(41.7 \%)$; and in the $3 \mathrm{rd}$ year the increased length was $19.2 \mathrm{~mm}(17.9 \%)$. The increase in the length of 
the first stage helps Gerres filamentosus avoid predatory fish and they can soon reach sexual maturity status to participate in the reproductive process of population $[6,8]$.

\subsection{Growth equation of Gerres filamentosus}

The parameters of the Von Bertalanffy growth equation about the length and weight of Gerres filamentosus were defined in Table 3.

The results showed that Gerres filamentosus could reach a maximum weight of $373.4 \mathrm{~g}$, with a body length was $234.4 \mathrm{~mm}$. Partition coefficient of the protein length $(\mathrm{k}=$ $0.3500)$ was greater than the weight $(\mathrm{k}=0.0244)$. It shows that Gerres filamentosus individuals were too small to be exploited, so that the quality and commercial values were not high. It is necessary to exploit the fish with the size and weight consistent with the $\mathrm{L}$ and $\mathrm{W}$ parameters mentioned above. Based on the results obtained, we formulate the Von Bertalanffy growth as follows:

Length: $\mathrm{L}_{\mathrm{t}}=234.4 \times\left[1-\mathrm{e}^{-0.35(\mathrm{t}+0.996)}\right]$,

Volume: $\mathrm{W}_{\mathrm{t}}=373.4 \times\left[1-\mathrm{e}^{-0.0244(\mathrm{t}+0.2388)}\right]^{3.0676}$

\subsection{Sustainable solutions to protect Gerres filamentosus resources in the coastal area of Quang Binh province}

\subsubsection{Technical solutions}

The types of gears for catching Gerres filamentosus fishes such as gill nets, trigrams traps ensure greater grid from $2 \mathrm{a}$ $=200 \mathrm{~mm}$ or more, which were used for the purpose of uneradicated fishing. The minimum distance of fish traps is $150 \mathrm{~m}$. The number of stake traps and trigrams traps continue to be reduced because of being replaced by other gears. In practice, the local authorities should implement measures to improve catching in a natural way, prevent the catching style of destruction of fish and aquatic environment inn the region such as using mines and electric power pulses.

\subsubsection{Organizational solutions}

The organization of exploitation and protection of Gerres filamentosus fish stocks of the Department of Agriculture and Rural Development should be strengthened with enough resources and equipments to better implement of the tasks assigned. Moreover, we need to coordinate closely this organization with local fishery association to give information and educate fishermen to resolutely follow the fishing regulations in the province.

\subsubsection{Administrational and media solutions}

The information about development plans of Gerres filamentosus farming should be announced so that the people can carry out. Besides, training courses on the principle of protecting aquatic resources need to be held for the fishermen and the staff of the village with the aims that they can become key members in propagating the protection of aquatic resources in general and Gerres filamentosus resources in particular.

\subsubsection{Economic Solutions}

Fishermen should be encouraged to exploit reasonably, and strengthen the offshore fishing with long journeys at sea, in order to reduce pressure of catching near the coast and estuary to ensure the sustainable development of fishing.

\section{Conclusion}

Gerres filamentosus exploited in the coastal zone of Quang Binh province has average the length ranging from 52$230 \mathrm{~mm}$, corresponding to the weight from $4-185 \mathrm{~g}$. At an early life stage the fishes grow fast in length. However, at the following life stages they grow fast in weight. The correlation between the length and weight is shown by the following equation: $\mathrm{W}=5204 \times 10^{-8} \times \mathrm{L}^{2.9367}$.

Age structure of Gerres filamentosus fish populations includes 4 groups, from $0+$ to $3^{+}$. In particular, the $2^{+}$age group accounts for the highest percentage (34.65\%), followed by the age group $1^{+}, 3^{+}$and $0^{+}(25.69 \%, 19.76 \%$, and $14.59 \%$ respectively). The growth rate of Gerres filamentosus is fairly quick. The highest growth value of fish belongs to the first year ( $93.5 \mathrm{~mm}$ in length); it increases $42.2 \mathrm{~mm}$ in the $2 \mathrm{nd}$ year and $19.2 \mathrm{~mm}$ in the $3 \mathrm{rd}$ year. The Von Bertalanffy growth equation is as follows: Length: $\mathrm{L}_{\mathrm{t}}=234.4 \times\left[1-\mathrm{e}^{-0.35(\mathrm{t}+0.996)}\right]$,

Volume: $\mathrm{W}_{\mathrm{t}}=373.4 \times\left[1-\mathrm{e}^{-0.0244(\mathrm{t}+0.2388)}\right]^{3.0676}$

\section{References}

[1] Das. M. 1994. Age Determination and longetevity in Fishes. Gerontology 40 (24): 70-76.

[2] Das. NG. et al. 1997. Length - weight relationship and condition factor of catfish Arius tenuispinis, Day 1877, Indian J.Fish. 44(1): 81 - 84.

[3] Kader MA, Rahman MM, 1987. The lengh - weight relationship and condition factor of tilapia (Tilapia mossambia, Peters). J.Asiatic. Soc. Bangladest Sci. 3(2): 1-17.

[4] Mai, D.Y. et al.. 1979. Fishing Anthropology, University Publishing House and vocational schools, Hanoi.

[5] Nguyen, V.H., 2005. Vietnam Freshwater fish, Episode 3, Agricultural Publishing House, Hanoi.

[6] Pham, T.L., Tran, D.D..2004 Syllabus research methods fisheries biologist, Can Tho University bookstore.

[7] Pravdin. I. F, 1973. Research Guide fish, Science and Technology Publishing House, Hanoi.

[8] Tran, K., 1978. Animal Ecology, Education Publishing House, Hanoi. 